\title{
Entrepreneurial Competencies and Readiness of Extension Service Beneficiaries of a State University
}

\author{
Desiree Joy D. Perez ${ }^{1}$ and Joseph G. Guevarra ${ }^{2}$ \\ ${ }^{1}$ Central Philippines State University, Kabankalan City, Philippines \\ ${ }^{2}$ University of Negros Occidental-Recoletos, Bacolod City, Philippines
}

\begin{tabular}{l} 
Article history: \\
Submitted: 22 October 2020 \\
Revised: 13 December 2020 \\
Accepted: 31 December 2020 \\
\hline Keywords: \\
Business management \\
Entrepreneurship \\
Entrepreneurial competencies \\
Entrepreneurial readiness \\
Human capital \\
Descriptive research \\
Negros Occidental \\
Philippines
\end{tabular}

Article history:

Submitted: 22 October 2020

ABSTRACT. Entrepreneurship as a pillar of a country's economy improves the quality of life of the people. Using the descriptive research design, the study aimed to assess the entrepreneurial competencies and readiness of extension and community service beneficiaries of training on transferred technology of a state university in Negros Occidental, Philippines. A researcher-made questionnaire was utilized to gather data from randomly selected respondents. Using mean, results showed moderate entrepreneurial competencies and high entrepreneurial readiness. Likewise, the results of Kruskal Wallis revealed that significant differences occurred both in competency and readiness when respondents are grouped by educational attainment and entrepreneurial training. Moreover, employing Spearman rho, a significant relationship was found between entrepreneurial competencies and readiness. Findings aver that the economic advancement of the individual is a result of investment in human capital. In view of community empowerment, the entrepreneurship development plan formulated will supplement the existing program of the institution.

\subsection{Introduction}

Entrepreneurial activities emerged as a prominent goal for several national governments worldwide in response to the current economic challenges (Al Mamum, Kumar, Ibrahim, \& Yusoff, 2017). However, constraints in developing start-ups into established businesses were experienced in several countries, as reported in Global Entrepreneurship Monitor (Amoros \& Bosma, 2014). The absence of competence highly contributes to low entrepreneurial activity (Zizile \& Tendai, 2018). Previous research noted that the lack of general business knowledge is one of the difficulties faced by individuals planning to establish a business (Staniewski \& Szopinski, 2015). Countries with low technical and business skills could prevent those who are motivated to start a venture (Genty, Idris, Wahat, \& Kadir, 2015). Its absence results in untapped business opportunities (Baringer \& Ireland, 2015). Meanwhile, higher levels of these activities are likely to be found in countries where business and entrepreneurship knowledge and skills are more widespread (Urbano \& Alvarez, 2014).

The importance of entrepreneurial competencies has been widely recognized (Gustomo, Herliana, Dhewanto, \& Ghina, 2017), and several studies have considered it critical for launching a venture (Zarefard \& Cho, 2018). Likewise, for entrepreneurship to concur, individuals should have readiness factors that predispose them to think to have a business (Ntale, Anampiu, \& Gathaiya, 2015).

In the Philippines, entrepreneurship is the key driver of the economy (Ramos, 2014) and is used as the best alternative for financial independence and self-sustainability. However, its development is beset with critical challenges, and among those identified by the United Nations Development Program are access to knowledge and skills development (Evangelista, 2013). Furthermore, it ranked poor among the 189 countries for ease of starting a business in doing business report (Bieri, 2016).

The significance of developing competencies in the context of a micro business in the informal sector is particularly strong. It has been a recent research topic that needs to be studied further (Mukherjee, 2016). There have been notable studies on the skills and competencies, but each is, to some extent, context-dependent (Mitchelmore \& Rowley, 2013). Venture emergence as an essential phase has not received adequate attention in human capital research (Marvel, Davis, \& Sproul, 2014). It needs continuous research on how to increase start-up performance (Kallas, 2019).

Regarded as crucial to entrepreneurship, this study underscored the importance of fostering entrepreneurial competencies and readiness in the community context in line with the institution's goal of community empowerment. The current study assessed the entrepreneurial competencies and readiness of the beneficiaries when grouped according to their profile characteristics. Hence, it aimed to determine the level of their competency and extent of readiness. Likewise, to explore if there exists a relationship between entrepreneurial competencies and readiness. 


\subsection{Framework of the Study}

The study theorized that a high level of entrepreneurial competencies may influence readiness to do business and is underpinned by the theories discussed.

Human capital (Becker, 1964) was traditionally conceptualized as knowledge, skills, and learning by doing that has economic value. According to Marvel et al. (2014), this theory is longstanding and increasingly applied in entrepreneurship. Their study articulated that entrepreneurial competencies are focused at the individual level. It deconstructed the complexity of human capital and identified dimensions such as knowledge, skills, and abilities to capture the outcomes believed of higher value to entrepreneurship.

Meanwhile, according to Fayolle, Liñan, and Mariano (2014) and Zarefarad and Cho (2018) in analyzing entrepreneurial phenomena, one of the most influential theories is the Planned Behaviour of Ajzen (1991). Generally, it assumes that the more favorable the attitude, the stronger an individual will perform the behavior. While, Entrepreneurial Event Model (Shapero \& Sokol, 1982) suggests that an individual must perceive the idea of starting a business as credible and finds it attractive and achievable.

Ntale et al. (2015) suggest that entrepreneurial readiness is composed of the elements that predispose and prepare a person to think or to have business ideas. Ghazalan et al. (2018) identified motivation as one indicator to measure readiness to venture into entrepreneurship. This may include a need for self-achievement (Olugbola, 2017), desire for independence, and family-related factors (Atef \& Al-Balushi, 2015). In contrast, De Clercq et al. (2013) consider intention as the readiness to carry out particular behavior to show the self-acknowledged conviction of the individual that plans to create a business. Perceived desirability and feasibility are the significant aspects of controlling a person's intention to initiate a business supported by the propensity to act (Ndaghu, Gwems, Wajiga, \& Augustine, 2016).

Generally, humans do not engage in an entrepreneurial venture by accident (Marvin \& Flora, 2014) since actions are preceded by a conscious decision to behave in a particular way (Azjen, 1991).

\subsection{Methods}

The study employed a descriptive-correlational research design. The descriptive method involved data on demographic profile, entrepreneurial competencies, and readiness. These were gathered, analyzed, and interpreted. Meanwhile, a correlation was used to measure the relationship and if sufficient magnitude exists between these variables.

Stratified random sampling was employed with different technologies as strata to identify the 179 respondents who were beneficiaries of training in transferred technology conducted in the $3^{\text {rd }}$ quarter of 2019. Their current status and experiences were considered relevant to provide the data. The study utilized a researcher-made questionnaire structured based on the review of the existing related literature on entrepreneurship such as Entrepreneurship Management Skills Requirements in an Emerging Economy (Mamabolo, Kerrin, \& Kele, 2017), Entrepreneurs' Managerial Competencies and Innovative Start-up Intentions In University Students: Focus on Mediating Factors (Zarefard \& Cho, 2018), Entrepreneurial Orientation and Antecedents of Low-Income Household Heads in Kelantan (Kumar, Al Mamum, Ibrahaim, \& Yusoff, 2018) and others as discussed in the related literature. It was translated into vernacular for ease of understanding and composed of three (3) parts. Part I determined the respondents' profile. Part II consists of items that measured the entrepreneurial competencies, and Part III explored the extent of entrepreneurial readiness. Each section has multiple questions that covered different parameters and were answered using a 5-point Likert scale. Said questionnaire was subjected to content validity by ten experts in entrepreneurship and business management using the Content Validity Ratio (CVR) of Lawshe (1975). A content validity index of 0.858 was obtained and interpreted as valid. Likewise, a pilot test was conducted to assess the instrument's reliability. Cronbach's Alpha was employed and showed a result of 0.935 for competency and 0.976 for readiness. Both are interpreted as highly reliable. Consent from the participants and utmost confidentiality was observed in the conduct of the study.

Descriptive objectives were analyzed using descriptive statistics such as frequency, percentage, mean and standard deviation. Meanwhile, Kolmogorov-Smirnov was used to determine the normality of the data and revealed that the variable competency $[K S=0.123, p=0.000]$ and readiness $[K S=0.199$, $p=0.000]$ are not normally distributed. Therefore, statistical tools without the assumption of normality 
were used in the inferential statistics, such as Mann Whitney $U$ and Kruskal Wallis. Meanwhile, to determine the relationship between entrepreneurial competencies and readiness, a Spearman Rank Correlation was used.

\subsection{Results and Discussion}

\section{Profile of the respondents}

Table 1 presents the profile characteristics that were considered in the conduct of the study. The survey results showed that the majority are adults, $50.8 \%(n=91)$, and were predominantly participated by females $73 \%(n=130)$. As to educational attainment, the data depict that most of the respondents are high school graduates, $23.5 \%(n=42)$. Majority are with business experience, $70.4 \%$ $(n=126)$, and have undergone entrepreneurial training $69 \%(n=124)$.

Table 1. Profile of the Respondents

\begin{tabular}{|c|c|c|c|c|c|}
\hline Variable & $f$ & $\%$ & Variable & $f$ & $\%$ \\
\hline Age & & & Educational Attainment & & \\
\hline Young Adults $(<40)$ & 61 & 34.08 & Elementary Level & 36 & 20.69 \\
\hline Adults (41- 60) & 91 & 50.84 & Elementary Graduate & 19 & 10.92 \\
\hline Old $(>60)$ & 27 & 15.08 & High School Level & 31 & 17.82 \\
\hline Total & 179 & 100.00 & High School Graduate & 42 & 24.14 \\
\hline Sex & & & College Level & 18 & 10.34 \\
\hline Male & 48 & 26.97 & College Graduate & 28 & 16.09 \\
\hline Female & 130 & 73.03 & Total & 79 & 100.00 \\
\hline Total & 179 & 100.00 & Entrepreneurial Training & & \\
\hline Business Experience & & & With & 124 & 75.61 \\
\hline With & 126 & 73.26 & Without & 40 & 24.39 \\
\hline Without & 46 & 26.74 & Total & 164 & 100.00 \\
\hline Total & 179 & 100.00 & & & \\
\hline
\end{tabular}

\section{Level of entrepreneurial competencies}

Table 2 shows the overall level of entrepreneurial competencies that is moderate $(M=3.35$; $\mathrm{SD}=0.59)$. Of the three (3) indicators to measure their competency, only ability $(M=3.54 ; S D=0.65)$ rated high. It suggests that the respondents perceived themselves to be creative, capable of the undertaking, and can cope with uncertainties. Meanwhile, both knowledge $(M=3.25 ; S D=0.66)$ and skills $(M=3.25 ; S D=0.67)$ are moderate. This implies that they fairly understand entrepreneurship and only possess reasonable skills to start and operate a business.

Concerning age, the level of competency is moderate in all ages. As to sex, the male $(M=3.69$; $S D=0.43)$ appears to be highly competent than the female. Also, college graduates $(M=3.84$; $\mathrm{SD}=0.25)$ are highly competent, indicating that competencies are acquired through education. Furthermore, with $(M=3.35 ; S D=3.24)$ or without $(M=3.32 ; S D=0.53)$ business experience, the competency of respondents rated moderate. Lastly, those with entrepreneurial training $(M=3.50$; $\mathrm{SD}=0.51$ ) are highly competent and suggests that training allowed them to acquire the competencies fundamental in entrepreneurship. 
Table 2. Level of entrepreneurial competencies

\begin{tabular}{|c|c|c|c|c|c|c|c|c|c|c|c|c|}
\hline \multirow{2}{*}{ Variable } & \multicolumn{3}{|c|}{ Competency } & \multicolumn{3}{|c|}{ Knowledge } & \multicolumn{3}{|c|}{ Skill } & \multicolumn{3}{|c|}{ Ability } \\
\hline & $M$ & SD & Int & M & SD & Int & M & SD & Int & M & SD & Int \\
\hline \multicolumn{13}{|l|}{ Age } \\
\hline Young Adults & 3.17 & 0.08 & Mo & 3.06 & 0.09 & Mo & 3.11 & 0.09 & Mo & 3.23 & 0.09 & Mo \\
\hline Adults & 3.37 & 0.06 & Mo & 3.27 & 0.07 & Mo & 3.26 & 0.07 & Mo & 3.59 & 0.06 & $\mathrm{Hi}$ \\
\hline Old & 3.49 & 0.09 & Mo & 3.41 & 0.09 & Mo & 3.38 & 0.11 & Mo & 3.66 & 0.13 & $\mathrm{Hi}$ \\
\hline \multicolumn{13}{|l|}{ Sex } \\
\hline Male & 3.69 & 0.43 & $\mathrm{Hi}$ & 3.61 & 0.49 & $\mathrm{Hi}$ & 3.63 & 0.51 & $\mathrm{Hi}$ & 3.81 & 0.49 & $\mathrm{Hi}$ \\
\hline Female & 3.20 & 0.59 & Mo & 3.09 & 0.65 & Mo & 3.09 & 0.65 & Mo & 3.41 & 0.69 & Mo \\
\hline \multicolumn{13}{|l|}{ Educational Attainment } \\
\hline Elementary Level & 3.10 & 0.62 & Mo & 3.06 & 0.68 & Mo & 3.04 & 0.67 & Mo & 3.21 & 0.73 & Mo \\
\hline Elementary Graduate & 3.33 & 0.65 & Mo & 3.23 & 0.68 & Mo & 3.28 & 0.75 & Mo & 3.44 & 0.60 & Mo \\
\hline High School Level & 3.39 & 0.69 & Mo & 3.30 & 0.74 & Mo & 3.33 & 0.73 & Mo & 3.55 & 0.74 & $\mathrm{Hi}$ \\
\hline High School Graduate & 3.28 & 0.54 & Mo & 3.15 & 0.65 & Mo & 3.14 & 0.63 & Mo & 3.53 & 0.61 & $\mathrm{Hi}$ \\
\hline College Level & 3.42 & 0.42 & Mo & 3.33 & 0.49 & Mo & 3.29 & 0.52 & Mo & 3.64 & 0.53 & $\mathrm{Hi}$ \\
\hline College Graduate & 3.84 & 0.25 & $\mathrm{Hi}$ & 3.71 & 0.28 & $\mathrm{Hi}$ & 3.75 & 0.39 & $\mathrm{Hi}$ & 4.04 & 0.36 & $\mathrm{Hi}$ \\
\hline \multicolumn{13}{|l|}{ Business Experience } \\
\hline With & 3.35 & 0.53 & Mo & 3.24 & 0.60 & Mo & 3.26 & 0.61 & Mo & 3.54 & 0.63 & $\mathrm{Hi}$ \\
\hline Without & 3.32 & 0.73 & Mo & 3.23 & 0.79 & Mo & 3.23 & 0.79 & Mo & 3.49 & 0.73 & Mo \\
\hline \multicolumn{13}{|l|}{ Entrepreneurial Training } \\
\hline With & 3.50 & 0.51 & $\mathrm{Hi}$ & 3.41 & 0.57 & Mo & 3.42 & 0.56 & Mo & 3.64 & 0.59 & $\mathrm{Hi}$ \\
\hline Without & 2.91 & 0.61 & Mo & 2.75 & 0.68 & Mo & 2.73 & 0.70 & Mo & 3.24 & 0.75 & Mo \\
\hline As a Whole & 3.35 & 0.59 & Mo & 3.25 & 0.66 & Mo & 3.25 & 0.67 & Mo & 3.54 & 0.65 & $\mathrm{Hi}$ \\
\hline
\end{tabular}

Legend: $\mathrm{Mo}=$ Moderate, $\mathrm{Hi}=\mathrm{High}$

\section{Extent of entrepreneurial readiness}

Table 3 presents the overall extent of entrepreneurial readiness rated high $(M=3.91 ; S D=0.45)$. Results revealed that consistently respondents are highly ready when grouped according to their profile characteristics. This is cognizant of the findings that the formation of an intention to become an entrepreneur should always be coupled with motivation (Malebana, 2014) to transform it into actual action (Fayolle et al., 2014).

\section{Difference in the level of entrepreneurial competencies according to age}

The Kruskal Wallis result reveals no significant difference in the level of entrepreneurial competencies $(H=4.894 ; p=0.087)$ when grouped by age. Generally, it suggests that regardless of age, there is no difference in their competency, and it does not increase over time as they become old. Nonetheless, there is no enough evidence to support that age makes a difference in the competency of respondents. Hence, the study fails to reject the null hypothesis.

However, significant findings can be seen in terms of their knowledge $(H=6.746 ; p=0.034)$. The old $(M=3.41 ; S D=0.087)$ appears to be more knowledgeable compared to other respondents. This is parallel to the findings of Bosma, Praag, and Wit (2000), which affirm that knowledge is positively related to age. While no difference can be seen in their skills $(H=3.609 ; p=0.165)$ and abilities $(H=5.208 ; p=0.074)$, which implies that it does not improve over time with age. This is contrary to the findings of Welmilla, Weerakkody, and Ediriweera (2011) that individuals' skills improve with age. 
Table 3. Extent of entrepreneurial readiness

\begin{tabular}{|c|c|c|c|c|c|c|c|c|c|}
\hline \multirow{2}{*}{ Variable } & \multicolumn{3}{|c|}{ Readiness } & \multicolumn{3}{|c|}{ Motivation } & \multicolumn{3}{|c|}{ Intention } \\
\hline & $\mathrm{M}$ & SD & Int & $M$ & SD & Int & $\mathrm{M}$ & SD & Int \\
\hline \multicolumn{10}{|l|}{ Age } \\
\hline Young Adults & 3.71 & 0.08 & $\mathrm{Hi}$ & 3.76 & 0.08 & $\mathrm{Hi}$ & 3.66 & 0.08 & $\mathrm{Hi}$ \\
\hline Adults & 3.94 & 0.05 & $\mathrm{Hi}$ & 3.98 & 0.05 & $\mathrm{Hi}$ & 3.90 & 0.05 & $\mathrm{Hi}$ \\
\hline Old & 4.07 & 0.05 & $\mathrm{Hi}$ & 4.10 & 0.06 & $\mathrm{Hi}$ & 4.04 & 0.04 & $\mathrm{Hi}$ \\
\hline \multicolumn{10}{|l|}{ Sex } \\
\hline Male & 3.98 & 0.29 & $\mathrm{Hi}$ & 4.03 & 0.34 & $\mathrm{Hi}$ & 3.94 & 0.32 & $\mathrm{Hi}$ \\
\hline Female & 3.85 & 0.53 & $\mathrm{Hi}$ & 3.91 & 0.55 & $\mathrm{Hi}$ & 3.82 & 0.55 & $\mathrm{Hi}$ \\
\hline \multicolumn{10}{|l|}{ Educational Attainment } \\
\hline Elementary Level & 3.66 & 0.59 & $\mathrm{Hi}$ & 3.72 & 0.60 & $\mathrm{Hi}$ & 3.63 & 0.61 & $\mathrm{Hi}$ \\
\hline Elementary Graduate & 3.88 & 0.25 & $\mathrm{Hi}$ & 3.87 & 0.26 & $\mathrm{Hi}$ & 3.88 & 0.27 & $\mathrm{Hi}$ \\
\hline High School Level & 3.97 & 0.42 & $\mathrm{Hi}$ & 4.01 & 0.51 & $\mathrm{Hi}$ & 3.95 & 0.40 & $\mathrm{Hi}$ \\
\hline High School Graduate & 3.94 & 0.34 & $\mathrm{Hi}$ & 3.96 & 0.35 & $\mathrm{Hi}$ & 3.93 & 0.38 & $\mathrm{Hi}$ \\
\hline College Level & 3.91 & 0.43 & $\mathrm{Hi}$ & 4.04 & 0.49 & $\mathrm{Hi}$ & 3.82 & 0.46 & $\mathrm{Hi}$ \\
\hline College Graduate & 4.16 & 0.36 & $\mathrm{Hi}$ & 4.25 & 0.37 & $\mathrm{Hi}$ & 4.10 & 0.43 & $\mathrm{Hi}$ \\
\hline \multicolumn{10}{|l|}{ Business Experience } \\
\hline With & 3.94 & 0.46 & $\mathrm{Hi}$ & 3.99 & 0.48 & $\mathrm{Hi}$ & 3.91 & 0.49 & $\mathrm{Hi}$ \\
\hline Without & 3.76 & 0.50 & $\mathrm{Hi}$ & 3.81 & 0.53 & $\mathrm{Hi}$ & 3.73 & 0.51 & $\mathrm{Hi}$ \\
\hline \multicolumn{10}{|l|}{ Entrepreneurial Training } \\
\hline With & 4.00 & 0.36 & $\mathrm{Hi}$ & 4.05 & 0.41 & $\mathrm{Hi}$ & 3.97 & 0.37 & $\mathrm{Hi}$ \\
\hline Without & 3.62 & 0.58 & $\mathrm{Hi}$ & 3.69 & 0.62 & $\mathrm{Hi}$ & 3.59 & 0.59 & $\mathrm{Hi}$ \\
\hline As a Whole & 3.91 & 0.45 & $\mathrm{Hi}$ & 3.96 & 0.49 & $\mathrm{Hi}$ & 3.88 & 0.46 & $\mathrm{Hi}$ \\
\hline
\end{tabular}

Legend: : Mo=Moderate, $\mathrm{Hi}=\mathrm{High}$

Table 4. Difference in the level of entrepreneurial competencies when grouped according to age

\begin{tabular}{cccccc}
\hline Variable & $\begin{array}{c}\text { Young } \\
\text { Adults }\end{array}$ & Adults & Old & $\mathrm{H}$ & $\mathrm{p}$ \\
\hline \multirow{2}{*}{ Competency } & 3.17 & 3.37 & 3.49 & 4.894 & 0.087 \\
& $(0.082)$ & $(0.060)$ & $(0.094)$ & & \\
\hline \multirow{2}{*}{ Knowledge } & 3.06 & 3.27 & 3.41 & 6.746 & 0.034 \\
& $(0.087)$ & $(0.070)$ & $(0.087)$ & & \\
\hline \multirow{2}{*}{ Skill } & 3.11 & 3.26 & 3.38 & 3.609 & 0.165 \\
\hline Ability & $(0.086)$ & $(0.071)$ & $(0.108)$ & & 0.074 \\
& 3.23 & 3.59 & 3.66 & 5.208 & \\
\hline
\end{tabular}

Note: The difference is significant when $\mathrm{p} \leq 0.05$ 


\section{Difference in the level of entrepreneurial competencies according to sex}

Table 5 reveals that there is a significant difference in the level of entrepreneurial competencies $[\mathrm{U}=1562.5, \mathrm{p}=0.000]$ in terms of knowledge $[\mathrm{U}=1666.0, \mathrm{p}=0.000]$, skills $[\mathrm{U}=1605.5, \mathrm{p}=0.000]$, and abilities $[U=2021.5, p=0.000]$. It suggests that male respondents are entrepreneurially competent compared to female respondents. As gleaned from the table, the median scores of the indicators consistently showed that they are competent, and there is enough evidence to support that sex of the respondents makes a difference in their competency. Thus, the null hypothesis is rejected.

Accordingly, these differences can be observed in action patterns and perceptions about business (Dilli \& Westerhuis, 2018). Sajilan, Hadi, and Tehseen (2015) argued that few studies have considered gender to influence entrepreneurial competencies. Lindvert (2018) suggests that women's competencies in developing countries are challenged by constrained access to education and training. This also resonates with Ongachi and Bwisa (2013) that affirmed that reasons like lack of skills and experience and inability to perform multiple roles were among the factors that distress the growth of women-owned micro and small enterprise. In light of the results, the study suggests considering further studies related to it.

Table 5. Difference in the level of entrepreneurial competencies according to sex

\begin{tabular}{|c|c|c|c|c|}
\hline \multirow{2}{*}{ Variable } & \multicolumn{2}{|c|}{ Sex } & \multirow[b]{2}{*}{$U$} & \multirow[b]{2}{*}{$\mathrm{p}$} \\
\hline & Male & Female & & \\
\hline \multirow{2}{*}{ Competency } & 3.69 & 3.20 & $1562.5^{*}$ & 0.000 \\
\hline & $(0.43)$ & $(0.59)$ & & \\
\hline \multirow[b]{2}{*}{ Knowledge } & 3.61 & 3.09 & $1666.0^{*}$ & 0.000 \\
\hline & & $(0.65)$ & & \\
\hline \multirow{2}{*}{ Skill } & 3.63 & 3.09 & $1605.0^{*}$ & 0.000 \\
\hline & $(0.51)$ & $(0.65)$ & & \\
\hline \multirow{2}{*}{ Ability } & 3.81 & 3.41 & 2021.0* & 0.000 \\
\hline & $(0.49)$ & (0.69) & & \\
\hline
\end{tabular}

Note: *The difference is significant when $\mathrm{p} \leq 0.05$

\section{Difference in the level of entrepreneurial competencies according to educational attainment}

Table 6 shows the significant difference in the level of entrepreneurial competencies $\left[\chi^{2}(5)=19.284\right.$, $p=0.002]$ in terms of knowledge $\left[\chi^{2}(5)=13.983, p=0.016\right]$, skills $\left[\chi^{2}(5)=15.070, p=0.010\right]$, and abilities $\left[X^{2}(5)=20.092, p=0.001\right]$. It indicates that college graduates are competent compared to other respondents. Furthermore, post hoc tests using Scheffe revealed that they have significantly higher competency. Education helped them acquire competency necessary to become an entrepreneur. With this, there is enough evidence to support a difference in the competencies of those who have higher educational attainment. Thus, the null hypothesis is rejected. This is consistent with the findings of Umar, Cob, Omar, and Hamzah (2019) that suggest that those with higher educational attainment possess greater entrepreneurial competencies. Similarly, education allows an individual to acquire substantial knowledge and understanding, develop basic mental ability, and improve competencies that lead to self-employment (Genty et al., 2015).

\section{Difference in the level of entrepreneurial competencies according to business experience}

Table 7 shows that there is no significant difference in the level of entrepreneurial competencies $[U=2714.0, p=0.575]$ in terms of knowledge $[U=2787.5, p=0.759]$, skills $[U=2854.5, p=0.943]$, and abilities $[U=2806.5, p=0.811]$. This means that whether or not the respondents have business experience, it does not make them competent and that there is no enough evidence to support that business experience makes a difference in their competency. Therefore, the findings of the study fail to reject the null hypothesis. This is contrary to the findings of Isaga (2015) that argued that prior entrepreneurial experience is important because it is associated with business growth. Similarly, 
Sarasvathy, and Menon (2013) argued that these experiences are determinants of success or failure because the acquired knowledge has a significant impact on the management of new ventures.

Table 6. Difference in the level of entrepreneurial competencies according to educational attainment

\begin{tabular}{|c|c|c|c|c|c|c|c|c|c|}
\hline \multirow[b]{2}{*}{ Variable } & \multicolumn{6}{|c|}{ Educational Attainment } & \multirow[b]{2}{*}{$x^{2}$} & \multirow[b]{2}{*}{$d f$} & \multirow[b]{2}{*}{$\mathrm{p}$} \\
\hline & $\begin{array}{l}\text { Elementary } \\
\text { Level }\end{array}$ & $\begin{array}{c}\text { Elementary } \\
\text { Graduate }\end{array}$ & $\begin{array}{l}\text { High } \\
\text { School } \\
\text { Level }\end{array}$ & $\begin{array}{c}\text { High } \\
\text { School } \\
\text { Graduate }\end{array}$ & $\begin{array}{l}\text { College } \\
\text { Level }\end{array}$ & $\begin{array}{l}\text { College } \\
\text { Graduate }\end{array}$ & & & \\
\hline \multirow{2}{*}{ Competency } & 3.10 & 3.33 & 3.39 & 3.28 & 3.42 & 3.84 & $19.284^{\star}$ & 5 & 0.002 \\
\hline & $(0.62)$ & $(0.65)$ & (0.69) & $(0.54)$ & $(0.42)$ & $(0.25)$ & & & \\
\hline \multirow{2}{*}{ Knowledge } & 3.06 & 3.23 & 3.30 & 3.15 & 3.33 & 3.71 & $13.983^{*}$ & 5 & 0.016 \\
\hline & $(0.68)$ & $(0.68)$ & $(0.74)$ & $(0.65)$ & $(0.49)$ & $(0.28)$ & & & \\
\hline \multirow{2}{*}{ Skill } & 3.04 & 3.28 & 3.33 & 3.14 & 3.29 & 3.75 & $15.070^{\star}$ & 5 & 0.010 \\
\hline & $(0.67)$ & $(0.75)$ & $(0.73)$ & $(0.63)$ & $(0.52)$ & $(0.39)$ & & & \\
\hline \multirow{2}{*}{ Ability } & 3.21 & 3.44 & 3.55 & 3.53 & 3.64 & 4.04 & $20.092^{\star}$ & 5 & 0.001 \\
\hline & $(0.73)$ & $(0.60)$ & $(0.74)$ & $(0.61)$ & $(0.53)$ & $(0.36)$ & & & \\
\hline
\end{tabular}

Note: *The difference is significant when $\mathrm{p} \leq 0.05$

Table 7. Difference in the Level of Entrepreneurial Competencies according to business experience

\begin{tabular}{ccccc}
\hline Variable & $\begin{array}{c}\text { With Business } \\
\text { Experience }\end{array}$ & $\begin{array}{c}\text { Without Business } \\
\text { Experience }\end{array}$ & $\mathrm{U}$ & $\mathrm{p}$ \\
\hline \multirow{2}{*}{ Competency } & 3.35 & 3.32 & 2714.0 & 0.575 \\
& $(0.53)$ & $(0.73)$ & & \\
\hline \multirow{2}{*}{ Knowledge } & 3.24 & 3.23 & 2787.5 & 0.759 \\
& $(0.60)$ & $(0.79)$ & & \\
\hline \multirow{2}{*}{ Skill } & 3.26 & 3.23 & 2854.5 & \\
& $(0.61)$ & $(0.79)$ & & 0.811 \\
\hline
\end{tabular}

Note: The difference is significant when $p \leq 0.05$

\section{Difference in the level of entrepreneurial competencies when grouped according to entrepreneurial training}

Table 8 discloses that there is a significant difference in the level of entrepreneurial competencies $[U=1213.5, p=0.000]$ in terms of knowledge $[U=1096.0, p=0.000]$, skills $[U=1133.5, p=0.000]$, and abilities $[\mathrm{U}=1721.5, p=0.004]$. This indicates that those who have training experience have a higher level of competency, and their experience in training allowed them to acquire the competency necessary to becoming an entrepreneur. This supports the claim that there is a difference in the competency of those who have undergone entrepreneurial training. Hence, the null hypothesis is rejected. Similarly, various studies have contended that in training, skills are particularly attained and developed (Abdul, 2018; Mamabolo et al., 2017; Zulfiqar, Asmi, Chandia, Sarwar \& Aziz, 2017; Lamki, Al-Sumri, Al-Ismali, \& Al-Busaidi, 2016). Furthermore, it has a significant impact on the key aspects of entrepreneurship (Genty et al., 2015; Torikka, 2013). 
Table 8. Difference in the level of entrepreneurial competencies according to entrepreneurial training

\begin{tabular}{ccccc}
\hline Variable & With & Without & $\mathrm{U}$ & $\mathrm{p}$ \\
\hline \multirow{2}{*}{ Competency } & 3.50 & 2.91 & $1213.5^{*}$ & 0.000 \\
Knowledge & $(0.51)$ & $(0.61)$ & & \\
& 3.41 & 2.75 & $1096.0^{*}$ & 0.000 \\
Skill & $(0.57)$ & $(0.68)$ & & 0.000 \\
& 3.42 & 2.73 & $1133.5^{*}$ & \\
Ability & $(0.56)$ & $(0.70)$ & & 0.004 \\
& 3.64 & 3.24 & $1721.5^{*}$ & \\
\hline
\end{tabular}

Note: ${ }^{*}$ The difference is significant when $\mathrm{p} \leq 0.05$

\section{Difference in the extent of entrepreneurial readiness according to age}

Table 9 shows no significant difference in the overall entrepreneurial readiness $(H=8.393$; $p=0.051$ ) of respondents. It indicates that they are entrepreneurially ready, regardless of age. However, significant findings can be seen in terms of intention $(H=11.237 ; p=0.004)$, which suggests that their intention increases over time with age. The older they become, the more they intend to engage in entrepreneurial activity. The result disputes the findings of Tanver, Akbar, Gill, and Ahmed (2013), which contends that as age increases, there is a lesser chance of becoming an entrepreneur. It has also noted studies with similar views that younger ages tend to start their business. Though older generations get more opportunities, their willingness to become an entrepreneur decreases as they become old. Nevertheless, as gleaned from the results, there is no sufficient evidence to support the claim that age makes a difference in the readiness of respondents. Therefore, the study fails to reject the null hypothesis.

Table 9. Difference in the extent of readiness according to age

\begin{tabular}{cccccc}
\hline Variable & Young Adults & Adults & Old & $\mathrm{H}$ & $\mathrm{p}$ \\
\hline \multirow{2}{*}{ Readiness } & 3.71 & 3.94 & 4.07 & 8.393 & 0.051 \\
& $(0.080)$ & $(0.047)$ & $(0.046)$ & & \\
Motivation & 3.76 & 3.98 & 4.10 & 5.903 & 0.052 \\
& $(0.082)$ & $(0.051)$ & $(0.064)$ & & \\
Intention & 3.66 & 3.90 & 4.04 & 11.237 & 0.004 \\
\hline Note: The difference is significant when $\mathrm{p}<0.05$ & $(0.050)$ & $(0.043)$ & & \\
\hline
\end{tabular}

\section{Difference in the extent of entrepreneurial readiness when grouped according to sex}

Table 10 shows that there is no significant difference in the extent of readiness $[U=2766.0$, $p=0.458]$ in terms of motivation $[U=2731.5, p=0.387]$ and intention $[U=2893.5, p=0.756]$. It implies that both male and female are entrepreneurially ready. The sex of the respondents does not make any difference in their readiness for entrepreneurial activity. At a $5 \%$ level of significance, there is no enough evidence to support that sex affects the readiness of the respondents. Hence, the study fails to reject the null hypothesis. The results do not concur with Dilli and Westerhuis (2018) that there is variability in the potential to become entrepreneurs by gender. Sajilan et al. (2015) noted previous research suggesting that gender is a predictor of intention and entrepreneurial behavior. Analysis of these studies revealed that males have high intentions as compared to females. This is confirmed in a recent study by Nguyen (2018) and with previous studies that men demonstrate a 
higher level. Generally, women have been reported to have a lower level of intentions. The likelihood or preference of women to start their own business is low.

Table 10. Difference in the extent of readiness according to sex

\begin{tabular}{|c|c|c|c|c|}
\hline \multirow{2}{*}{ Variable } & \multicolumn{2}{|c|}{ Sex } & \multirow[t]{2}{*}{$U$} & \multirow[t]{2}{*}{$p$} \\
\hline & Male & Female & & \\
\hline \multirow{2}{*}{ Readiness } & 3.98 & 3.85 & 2766.0 & 0.458 \\
\hline & $(0.29)$ & $(0.53)$ & & \\
\hline \multirow{2}{*}{ Motivation } & 4.03 & 3.91 & 2731.5 & 0.387 \\
\hline & $(0.34)$ & $(0.55)$ & & \\
\hline \multirow{2}{*}{ Intention } & 3.94 & 3.82 & 2893.5 & 0.756 \\
\hline & $(0.32)$ & $(0.55)$ & & \\
\hline
\end{tabular}

Note: The difference is significant when $\mathrm{p} \leq 0.05$

\section{Difference in the extent of entrepreneurial readiness when grouped according to educational attainment.}

Table 11 shows the significant difference in the extent of readiness $\left[\chi^{2}(5)=10.229, p=0.049\right]$ in terms of motivation $\left[\chi^{2}(5)=13.529, p=0.019\right]$ and intention $\left[\chi^{2}(5)=12.243, p=0.032\right]$. It implies that college graduates are more ready than other respondents. There is enough evidence to support the claim that educational attainment makes a difference in respondents' readiness towards the entrepreneurial activity. Hence, the null hypothesis is rejected. This resonates with Zulfiqar et al.'s (2017) contention that education provides knowledge and creates awareness and changes the attitude. Likewise, the intention to start a new business is likely to be found in individuals with higher educational attainment (Amoros \& Bosma, 2014). There is a positive relationship between educational level and desire to be entrepreneurial (Herrington, Kew, \& Kew, 2014).

Table 11. Difference in the extent of readiness according to educational attainment

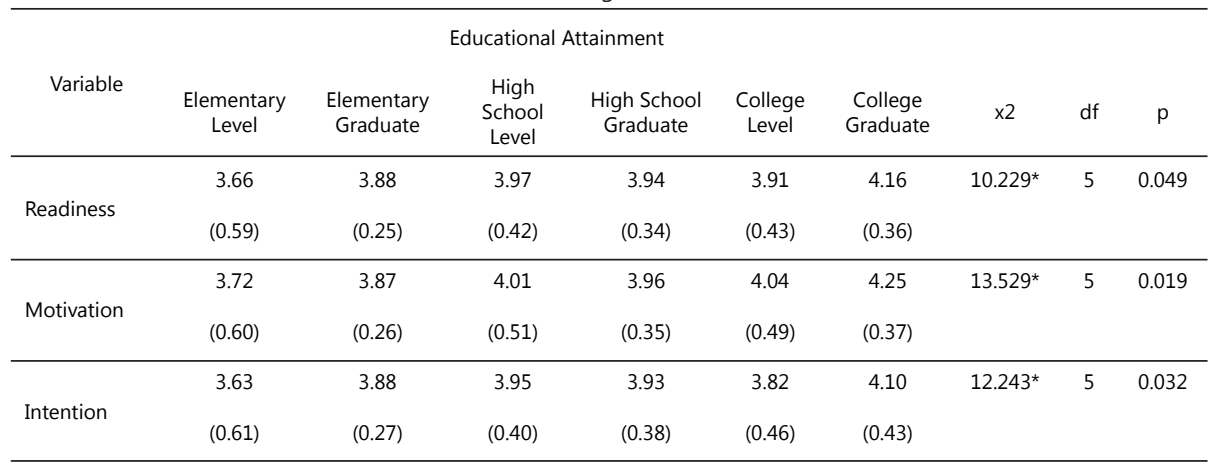

Note: *The difference is significant when $\mathrm{p} \leq 0.05$

\section{Difference in the extent of entrepreneurial readiness when grouped according to business experience}

Table 12 shows that there is no significant difference in the extent of readiness $[U=2284.5$, $p=0.072$ ] in terms of motivation [ $U=2270.0, p=0.062]$ and intention $[U=2312.0, p=0.087]$. It suggests that whether or not the respondents have business experience, they are ready both in their motivational and intentional aspects. There is no enough evidence to support that prior engagement in business will make a difference in their readiness. Therefore, the study fails to reject the null hypothesis. This does not concur with Nguyen's (2018) study, which affirmed that prior business experience does not support entrepreneurial intention. 
Table 12. Difference in the extent of readiness according to business experience

\begin{tabular}{lcccc}
\hline \multirow{2}{*}{ Variable } & \multicolumn{3}{c}{ Business Experience } & \\
& With & Without & $\cup$ & $\mathrm{p}$ \\
\hline \multirow{2}{*}{ Readiness } & 3.94 & 3.76 & 2284.5 & 0.072 \\
& $(0.46)$ & $(0.50)$ & & \\
Motivation & 3.99 & 3.81 & 2270.0 & 0.062 \\
& $(0.48)$ & $(0.53)$ & & \\
Intention & 3.91 & 3.73 & 2312.0 & 0.087 \\
\hline
\end{tabular}

Note: The difference is significant when $p \leq 0.05$

\section{Difference in the extent of entrepreneurial readiness according to entrepreneurial training}

Table 13 shows the significant difference in the extent of readiness $[U=1532.5, p=0.001]$ when grouped by entrepreneurial training. It indicates that those who have undergone entrepreneurial training are more ready. Their involvement in training makes a difference in their entrepreneurial readiness both in the motivational and intentional aspects. Thus, the null hypothesis is rejected. This affirmed the findings of Torrikka (2013) that training has a significant impact on decision-making, particularly on entrepreneurship aspects, such as intention, creation, and performance.

Table 13. Difference in the extent of readiness according to entrepreneurial training

\begin{tabular}{lcccc}
\hline \multirow{2}{*}{ Variable } & \multicolumn{2}{c}{ Entrepreneurial Training } & & \\
& With & Without & U & p \\
\hline \multirow{2}{*}{ Readiness } & 4.00 & 3.62 & $1532.5^{*}$ & 0.001 \\
& $(0.36)$ & $(0.58)$ & & \\
Motivation & 4.05 & 3.69 & $1645.5^{*}$ & 0.003 \\
& $(0.41)$ & $(0.62)$ & & \\
Intention & 3.97 & 3.59 & $1540.0^{*}$ & 0.001 \\
& $(0.37)$ & $(0.59)$ & & \\
\hline
\end{tabular}

Note: ${ }^{*}$ The difference is significant when $\mathrm{p} \leq 0.05$

\section{Relationship between entrepreneurial competencies and readiness}

Table 14 is the Spearman rank correlation that shows a significant relationship between entrepreneurial competencies and readiness $[\rho(173)=0.464, p=0.000]$. It indicates that both variables are significantly related. Likewise, the correlation coefficient signifies a positive relationship, which implies that with an increase in the competencies of the respondents, their readiness also increases. This means that a respondent who is entrepreneurially competent is also entrepreneurially ready. Their competency is a predictor of their readiness towards entrepreneurial activity. Developing the competencies of respondents would ultimately make them entrepreneurially ready. Thus, the null hypothesis is rejected. The result of the study is parallel to the findings of Kallas (2019) that one crucial aspect that determines readiness is competence, and a higher level of competency, motivation, and positive attitude leads to higher intentions of starting a business. Likewise, Santos, Caetano, and Curral (2013) also aver that entrepreneurial competencies and motivations impact intentions.

Table 14. Relationship between entrepreneurial competencies and readiness

\begin{tabular}{cccc}
\hline Variable & $\rho$ & $\mathrm{df}$ & $\mathrm{p}$ \\
\hline Competency $x$ Readiness & 0.464 & 173 & 0.000 \\
\hline
\end{tabular}

Note: The relationship is significant at 0.05 . 
The economic advancement of beneficiaries is central to entrepreneurship and congruent with the human capital theory. Nevertheless, entrepreneurs are made, and its process requires an infusion of competencies. The profile of the beneficiaries, particularly education and training, should never be static to steer entrepreneurship since it would allow them to acquire fundamental knowledge, skills, and abilities related to it.

The theory of planned behavior is also validated. Their motivation and intention to engage in business is evident in the positive attitude, social reference, and belief in one's ability to control the endeavor. It also affirmed the entrepreneurial event model that controlling a person's intention to engage in business emanates from their perceived desirability and feasibility of the business. They are certain to take action on it.

\subsection{Conclusion}

The presence of higher education institutions is found to play a crucial role in community empowerment through its extension and community service unit. With its aim of improving the community's general well-being, the training programs afforded should be tailored according to the beneficiaries' prevalent needs.

The study offers evidence that necessitates appropriate business education in the program and shall form part of the training. It highlighted education and training to have a valuable effect since those who have higher educational attainment and undergone training was found to be entrepreneurially competent and ready. Consequently, the training should not only be technology-driven but, at the same time, should provide practical knowledge and skills from the lens of an entrepreneur to be an effective means of fostering self-sufficiency and self-reliance. In this light, the ECS unit may revisit the training design and consider changes to fit the outcome in the business context.

\section{REFERENCES}

Abdul, O. (2018). Entrepreneurial Skills and Growth of Small and Medium Enterprise (SMEs): A Comparative Analysis of Nigerian Entrepreneurs and Minority Entrepreneurs in the UK. International Journal of Academic Research in Business and Social Sciences, E-ISSN: 2222-6990 Volume 8, No. 5.

Ajzen, I. (1991). The Theory of Planned Behavior. Organizational Behavior and Human Decision Process.50 (2), pp. $179-211$.

Al Mamum, A., Kumar, N., Ibrahim, M., \& Yusoff, H. (2017). Establishing a Valid Instrument to Measure Entrepreneurial Knowledge and Skill. Business Perspectives and Research, Volume 6(1). doi.10.1177/2278533717730449

Amoros, J.E. \& Bosma, N. (2014). Global Entrepreneurship Monitor 2013 Global Report, Global Entrepreneurship Research Association, London, United Kingdom

Atef, T. M. \& Al-Balushi, M. (2015). Entrepreneurship as a Means for Restructuring Employment Patterns. Tourism and Hospitality Research.15, 73-90.

Barringer, B.R. \& Ireland, R.D. (2015). Entrepreneurship: Successfully Launching New Ventures $5^{\text {th }}$ edition. Prentice-Hall.

Becker, G.S. (1964). Human Capital Theory. Retrieved from https://www.sciencedirect.com

Bieri, N. (2016). Developing Filipino Entrepreneurs: Case by Case. RTI International.

Bosma, N., Praag, M.V., \& Wit, G.D. (2000). Determinants of Successful Entrepreneurship SCALES. Ministry of Economic Affairs, Netherlands: Research Report 0002/E.

De Clercq, D., Dimov, D., \& Thongpapanl, N.T. (2013). Organizational Social Capital, Formalization, and Internal Knowledge Sharing in Entrepreneurial Orientation Formation. Entrepreneurship Theory and Practice. 37(3), 505-537.

Dilli, S. \& Westerhuis, G. (2018). How Institutions and Gender Differences in Education Shape Entrepreneurial Activity: A CrossNational Perspective. Small Business Econ., 51, 371-392.

Evangelista, R. P. (2013). Entrepreneurship in the Philippines: Opportunities and Challenges for Inclusive Growth. Retrieved from: http://www.cipe.org

Fayolle, A., Liñan, F., \& Moriano, J. A. (2014). Beyond Entrepreneurial Intentions: Values and Motivations in Entrepreneurship. International Entrepreneurship and Management Journal, 10(4), 679-689.

Genty, K., Idris, K., Wahat, N., \& Kadir, S. (2015). Demographic Factors and Entrepreneurial Success: A Conceptual Review. International Journal of Management Sciences. Vol. 6, No. 8, 366-374. Retrieved from: https://www.researchgate.net/publication/292615385

Ghazalan, M. S., Samad, N., Ab Halim, F., Hamidon, N.I., \& Ahmad Hariri A., T. (2018).Level Readiness Participant of Lifelong Learning (LLL) Program Venture into Entrepreneurship. MATEC Web of Conferences 150. Retrieved from: https://doi.org/10.1051/ matecconf/20185005029

Gustomo, A., Herliana, S., Dhewanto, W., \& Ghina, A. (2017). Building a Conceptual Framework of Entrepreneurial Competencies: The Ontological, Epistemological, and Methodological View. International Journal of Applied Business and Economic Research. ISSN: 0972-7302, Volume 15, Number 10. Retrieved from: https://www.researchgate.net/publication/318011530.

Herrington, M., Kew, J., \& Kew, P. (2014). GEM 2014 Sub-Saharan Africa Report, Global Entrepreneurship Research Association, Cape Town.

Isaga, N. (2015). Owner-Managers' Demographic Characteristics and the Growth of Tanzanian Small and Medium Enterprises. International Journal of Business and Management.10 (5).

Kallas, E. (2019). Environment-Readiness Entrepreneurship Intention Model: The Case of Estonians and the Russian-Speaking Minority in Estonia. SAGE Open. doi:10.1177/2158244018821759

Kumar, N., Al Mamum, A.D., Ibrahaim, M.D., \& Yusoff, M. (2018). Entrepreneurial Orientation and Antecedents of Low-Income Heads in Kelantan, Malaysia. Journal of International Studies. 11 (1), 140-151. doi:10.14254/2071-8330.2017/11-1/10

Lamki, R. Al-Sumri, M., Al-Ismali, S., \& Al-Busaidi, K. (2016). An Expert System to Determine the Probability of Success and Readiness in Entrepreneurship. International Journal of Computing \& Information Sciences. Vol.12, No. 2.

Lindvert, M. (2018). Resource Acquisition and the Complexity of Social Capital Perspectives from Women Entrepreneurs in Tanzania and Pakistan. Ph.D. Thesis, Mid Sweden University Ostersund.

Malebana, M. (2014).Entrepreneurial Intentions and Entrepreneurial Motivation of South African Rural University Students. Journal of Economics and Behavioral Studies. Vol. 6, No. 9, pp. 709-726. 
Mamabolo, M. A., Kerrin, M., \& Kele, T. (2017). Entrepreneurship Management Skills Requirement in an Emerging Economy: A South African Outlook. The Southern African Journal of Entrepreneurship and Small Business Management. ISSN: (Online) 2071-3185. https://doi.org/10.4102/sajesbm.v9i1.111

Marvel, M., Davis, J., \& Sproul, C. (2014). Human Capital and Entrepreneurship Research: A Critical Review and Future Directions. Entrepreneurship Theory and Practice. Retrieved from www.effectuation.org. doi: 10.1111/etap.12136

Marvin, M. E. \& Flora, T.P. (2014). An Investigation of Students' Readiness towards Entrepreneurial Intentions at Kigali Independent University (ULK). International Journal of Education and Research.Vol.2, No. 10.

Mitchelmore, S. \& Rowley, J. (2013). Entrepreneurial Competencies of Women Entrepreneurs Pursuing Business Growth". Journal of Small Business and Enterprise Development. 20(1), 125-142. doi.10.1108/14626001311298448

Mukherjee, S. (2016). Entrepreneurial Competencies of Women Owning Informal Sector Enterprises: A Case of India. Journal of Entrepreneurship Education. Volume 19, Number 2.

Ndaghu, J., Gwems, J., Wajiga, H., \& Augustine, M. (2016).Shapero's Model: A Veritable Tool for Explaining Entrepreneurial Intentions and Attitudes among Management Technology Students in Mautech Yola, Adamawa State, Nigeria. International Journal of Business and Management Invention. Volume 5, Issue 12.

Nguyen, C. (2018). Demographic Factors, Family Background, and Prior Self-Employment on Entrepreneurial Intention - Vietnamese Business Students are Different: Why? Journal of Global Entrepreneurship Research. 8 (10). https://doi.org/10.1186/s40497-0180097-3

Ntale, J., Anampiu, R., \& Gathaiya, C. (2015). Agro-Entrepreneurship Readiness Model: An Empirical Investigation in Kenya. International Journal of Development and Sustainability. ISSN: 2186-8662, Vol. 4, No. 7.

Ongachi, N. R. \& Bwisa, M. H. (2013). Factors Influencing Growth of Women-Owned Micro and Small Enterprises: A Survey of Kitale Municipality. International Journal of Academic Research in Business and Social Sciences. 3(10).

Olugbola, S. A. (2017). Exploring Entrepreneurial Readiness of Youth and Start-up Success Components: Entrepreneurship Training as Moderator. Journal of Innovation and Knowledge. Vol. 2. http://dx.doi.org/10.1016/j.jik.2016.12.004

Ramos, A. (2014). Entrepreneurial Intentions among Business Students at Batangas State University Asia Pacific Journal of Multidisciplinary Research, P-ISSN 2350-7756 Volume 2 No. 4.

Sajilan, S., Hadi, N., \& Tehseen, S. (2015). Impact of Entrepreneur's Demographic Characteristics and Personal Characteristics on Firm's Performance under the Mediating Role of Entrepreneur Orientation. Review of Integrative Business and Economics Research. Vol.4 (2). ISSN: 2304-1013 (Online). Retrieved from: https://www.sibreresearch.org

Santos, S. C., Caetano, A., \& Curral, L. (2013).Psychological Aspects of Entrepreneurial Potential. Journal of Small Business Entrep.26, 661-685.

Sarasvathy, J. C. \& Menon, A. R. (2013). Failing Firms and Success of Entrepreneurs: Serial Entrepreneurship as a Temporal Portfolio. Small Business Economics. 40, 417-434.

Shapero, A. \& Sokol, L. (1982).The Social Dimensions of Entrepreneurship. Encyclopedia of Entrepreneurship. Retrieved from: http:// ssm.com/abstract

Staniewski, M. \& Szopinski, T. (2015). Student Readiness to Start Their Own Business. Economic Research.Vol.28, No. 1. http://dx.doi.or g/10.1080/1331677X.2015.1085809

Tanveer, M. A., Akbar, A., Gill, H., \& Ahmed, I. (2013). Role of Personal Level Determinants in Entrepreneurial Firm's Success. Journal of Basic and Applied Scientific Research. 3(1), 449-458.

Torikka, J. (2013). Entrepreneurial Processes of the Finish Franchise Training Program's Graduates. In T. Ehrmann, J. Windsperger, G. Cliquet, \& G. Hendrikse (edx.), Network Governance (pp. 287-312). Berlin, Heidelberg: Springer Berlin Heidelberg.

Umar, A., Cob, C. M. S., Omar, C. M. Z., \& Hamzah, M. S. G. (2019).Determinants of Entrepreneurial Competencies Development in Small and Medium Enterprises. International Journal of Business and Management.Vol.14 (1). doi.10.5539/ijbm.v/4n1p147

Urbano, D. \& Alvarez, C. (2014). Institutional Dimensions and Entrepreneurial Activity: An International Study. Small Business Economics. 42(4), 703-716.

Welmilla, I. Weerakkody, W. A. S., \& Ediriweera, A. N. (2011). The Impact of Demographic Factors of Entrepreneurs on the Development of SMEs in the Tourism Industry in Sri Lanka. Faculty of Commerce and Management Studies, University of Kelaniya, Sri Lanka.

Zarefard, M., \& Cho, S. E. (2018). Entrepreneurs' Managerial Competencies and Innovative Start-up Intentions in University Students: Focus on Mediating Factors. International Journal of Entrepreneurship. Volume 22, Issue 2.

Zizile, T., \& Tendai, C. (2018). The Importance of Entrepreneurial Competencies on the Performance of Women Entrepreneurs in South Africa. The Journal of Applied Business Research. Volume 34, No. 2.

Zulfiqar, S., Asmi, F., Chandia, K., Sarwar, B., \& Aziz, S. (2017). Measuring Entrepreneurial Readiness among Youth in Pakistan through the Theory of Planned Behaviour (TBP) Based Approach. Business and Economic Research. ISSN: 2162-4860, Vol. 7, No. 1. doi.10.5296/ber.v7il.11037

\section{Correspondence:}

DESIREE JOY D. PEREZ

djdperez78@gmail.com

https://orcid.org/0000-0002-4704-8373

JOSEPH G. GUEVARRA

jguevarra6@gmail.com 